\title{
The Army as a Profession
}

\section{Major A. B. N. Churchill p.s.c.}

To cite this article: Major A. B. N. Churchill p.s.c. (1910) The Army as a Profession, Royal United Services Institution. Journal, 54:384, 166-198, DOI: $10.1080 / 03071841009425473$

To link to this article: http://dx.doi.org/10.1080/03071841009425473

\section{曲 Published online: 12 Nov 2009.}

Submit your article to this journal

Џll Article views: 12

Q View related articles $\sqsubset$ 


\section{THE ARMY AS A PROFESSION}

By Major A.B. N. CHURCHILL, p.s.c., Reserve of Officers (Gold Medallist, Royal United Service Institution).

On Vednesday, ist December, Igog.

The Right Honble. Viscount MIDLETow in the Chair.

THE subject which I have the honour to put before you for your consideration this afternoon has been described by Adam Smith as "certainly the noblest of all professions." Why is this so? Is it not because it is demanded of those who embrace the profession of arms that they should subordinate all personal interests to the public weal, and be ready at all times to give their lives for King and Country? Von der Goltz writes : "It is required of an officer that, in the interests of his service, he should forego personal advantage, lucre, and prosperity." A writer signing himself "Reserve" in a recent article in the National Defence Magasine, stated that "the number of those who join the Army for the honour and glory of serving their country is small indeed." Whether this is so or not, it is evident that among the large number who annually receive His Majesty's commission, such a motive will not be present in each individual in like degree. We may well admit with the author of "National Life and Character," that "a great many various motives contribute to form even a modern patriot"; but it is well to remember that the same writer states also that "in some particulars a lofty feeling of patriotism has become more possible now than it ever was in past centuries." In what section of the community do you expect to find the highest development of this lofty patriotism if not in those two great Services consecrated to the pursuit of arms?

$A$ high and noble ideal must animate those who engage into this noble profession or it is one no longer. It is very necessary, therefore, to provide for that education within the Army which inculcates and fosters the sentiment of which we have spoken. IVhile not less important is the development of that public spirit in the Service which wages ruthless war against all which savours of egotism, which is, in the words of Von der Goltz, "beyond all doubt the most bitter enemy of the qualities essential to the officer corps." In the British Army we have in esprit de corps an edu- 
cational factor of potent force and inestimable value; it is remarkable how quickly and effectively the young officer comes under its sway : there can be no doubt that at all events during his early years of service the officer learns to merge self in his regiment.

The longer the individual serves, the higher he advances in the Service, the more onerous and responsible the duties he is called on to carry out, and especially when he is called on to face the enemy, the greater the need that he should be fired by the sentiment of this high ideal. Personal advantage, lucre, and prosperity are not easier to forego as years advance, but very much the contrary. Thus it must be realised that the officer corps, to once more quote Von der Goltz, "has a certain character reminding us of the Orders in the heydey of their existence. It ought to be a real chivalry." What killed chivalry and what resulted therefrom? Sir Walter Scott tells us in his introduction to "Quentin Durward": "The scene of this romance," he begins, "is laid in the fifteenth century, when the feudal system, which had been the sinews and nerves of national defence, and the spirit of chivalry, by which, as by a vivifying soul, that system was animated, began to be innovated upon and abandoned by those grosser characters, who centred their sum of happiness in procuring the personal objects on which they had fixed their own exclusive attachment. The same egotism had indeed displayed itself even in the more primitive ages; but it was now for the first time openly avowed as a professed principle of action. The spirit of chivalry had in it this point of excellence : that, however overstrained and fantastic many of its doctrines may appear to us, they were all founded on generosity and selfdenial, of which if the earth were deprived it would be difficult to conceive the existence of virtue among the human race." $\mathrm{He}$ points out the prominent part played by Louis XI., and how that he possessed to a great extent that caustic wit which can turn into ridicule all that a man does for any other person's advantage but his own, and was therefore peculiarly qualified to play the part of a cold-hearted, sneering fiend. He shows "how the principles of chivalry were cast aside and their aid supplied by baser stimulants. Instead of the high spirit which pressed every man forward in defence of his country, Louis XI. substituted the exertions of the ever-ready mercenary soldier." I submit that the views of this great writer are worthy of deep consideration in an age when in all walks of life, puffing, thrust and selfadvertisement are rife-and seem to pay. It is impossible that the profession of arms should not become tainted with the fell disease of egotism, unless the sentiment which opposes it is inculcated. More especially is the danger great when special efforts are directed to making the service of arms more and more of a profession, using the word in its more commercial sense.

In the consideration of the Army as a profession I therefore, in the first place, lay the greatest stress on the necessity for the maintenance of that high ideal by which alone it takes 
rank as the noblest of all professions, and deprived of which it is debased to the career of a modernised mercenary. I urge that the sentiment which nurtures this ideal is of delicate structure, and that the cultivation and development of this sentiment must be studied and not treated with indifference; and lastly, that if you abandon that which does and will produce this sentiment, you do so at a great peril. In the words of Lord Wolseley : "The Army is governed largely by sentiment. - $\therefore$ You cannot flout the sentiment of the Army and not injure its moral."

The Source of Supply of Officers and Method of Selection.

I now ask you to consider the sources of supply and methods of selection adopted for recruiting the officer corps; and in this connection I propose to specially bring under review the subject of the shortage of candidates for the Army Entrance Examinations. The source of supply for officers in the opinion of Von der Goltz is as follows:- "Only such fractions of the population as are not, by reason of their vocation, compelled to prefer personal advantage to great and public ends, are fitting persons to recruit the corps of officers." In this country it was laid down by the Dufferin Committee in 1868 that the main principle is to secure a youth who has had a thoroughly well-grounded liberal education as an English gentleman. This principle has been endorsed by all subsequent committees which have dealt with the subject.

In later years this principle finds expression in the desire to obtain such youth direct from the public schools, and shortly after we find the term public school defined as meaning not a few of the more important schools, but all schools of a public character giving secondary education. The result of the measures taken by the Military Authorities and the Civil Service Commissioners were so successful that while in 1888 not more than 33 per cent. of the successful candidates for Woolwich came direct from the public schools, and not more than 12 per cent. in the case of Sandhurst, the figures had risen, so that for the years 1896 to 1900 they stood at 78.7 per cent. for TVoolwich and $55 \%$ per cent. for Sandhurst.

During these years you will find a very close relationship existing between the Military Authorities and the Civil Service Commissioners; so much so that in 1896 the latter took over much of the clerical work connected with the Entrance Examinations, which up to this time had been carried out by the military department, and at the same time an Order in Council was published by which the Civil Service Commissioners were constituted the advisers of the Secretary of State for War on educational matters. During the same period the Military Authorities will be found pressing for a higher educational standard, notably in respect to modern languages and science; but considerable difficulties were experienced by them in securing the necessary 
co-operation of the Headmasters of the public schools. With this important qualification, the military authorities and the Civil Service Commissioners were fully satisfied with the working of the system in force, and up to 1898 the standard steadily improved.

In 1901 the Akers-Douglas Committee considered among other matters this educational question. The report of this Committee led to very drastic changes being introduced, and one of the very first results was to rupture the very happy and close connection which, up to this time, had subsisted between the Military Authorities and the Civil Service Commissioners. The latter now ceased to be the educational advisers of the Secretary of State for $\mathrm{W}$ ar, and a newly-constituted Advisory Board took their place.

From an educational point of view the alteration made was of very far-reaching import. It may be doubted if the full consequences of the change made are yet realised; and the wisdom of the change is certainly debatable. Another great change to be noted is a departure in the policy hitherto pursued in connection with the public schools. The syllabus of the examinations are now framed so as to force the hands of the public schools in the matter of education. The new policy may be highly advantageous, but you have also to consider the merits of the means adopted to give effect to it. The view of the India Office, who had to consider this question, because the examination for admission to the Indian Police always is made to follow the lines of that laid down for Sandhurst was to this effect.

"This is an innovation of great importance which will no doubt make its influence felt on the system of education in public schools; but at the present time there would seem to be reasonable ground for apprehending that the enhanced value given to modern languages at the expense of classics, if embodied in the scheme for the police examination, may have an unfavourable effect in regard to candidates from the public schools who have pursued the ordinary classical course. it is interesting to note that in the case of Woolwich for the years 1905-08, there is a falling off of 18 per cent. in the direct candidate from the figures for $1896-1900$. It is not so easy to determine the figures for Sandhurst, but the fall is probably even more pronounced. The fall may, however, be due to other causes to be noted later on."

The third and last change to note, introduced by the AkersDouglas 'Committee, was a qualifying examination. 'This examination is of a quite different nature to the old qualifying examination abolished in the early nineties. Briefly, the examination consists of two.independent and distinct parts. A candidate must either obtain a "leaving certificate," which is only obtainable at those schools which conform to certain educational requirements, or he must obtain a qualifying certificate at a special examination. The official view of the Army Council 
in 1904 was as follows-please bear in mind the great object is to secure a youth direct from the public schools- "The examination for qualifying certificates may be considered to form part of the entrance examination for the Royal Military College and the Royal Military Academy, and need not require the same standard as that for leaving certificates. It has been decided to allow candidates who hold "leaving" certificates to be exempt from this portion of any entrapce examination, as they will have passed a higher test." 1 So yo see the Army Council there proposed to encourage a youth to pass from a public school by requiring him to undergo a more difficult test. You will not be surprised to find now a falling off in the candidates passing direct from the public schools.

However, educational experts hold very strongly the opinion that the qualifying examinations are so stiff that candidates become discouraged and give up the attempt; great objection is also taken to the dates fixed for these examinations as being inconvenient, more especially the Sepiember examination. Please examine the statistics I have prepared. You surely must admit the force of that opinion which holds that the shortage of candidates for the entrance examinations is an educational matter, entirely due to the methods in force with respect to the conduct of the qualifying examination.

It is well known that the Civil Service Commissioners conduct, and have long conducted, the competitive examinations for admission to Woolwich and Sandhurst. Now, when this qualifying examination was introduced, the Army Council were most anxious that the Civil Service Commissioners should carry out the examination. This, however, the Civil Service Commissioners found themselves unable to do. Most interesting and instructive is the correspondence on the subject recorded in the Parliamentary Papers; but I cannot dwell on it here. The net result has, however, been that the Army Council has taken on its own shoulders the conduct of this examination. In order to assist the Army Council, the London University has stepped in to afford facilities, but nothing more. This has led to the erroneous impression on the part of the public that the University carries out the examination. This is not the case : the selection of the examiners and everything of an educational nature connected with the qualifying examination is under the control of the Army Council.

I will now read to you the views of an educational expert on the work of the examiners in this Qualifying Examination :"The Army Qualifying Examination, as at present conducted, shows no appreciation of the real intentions of the Army Council. who drew up the scheme for the education of Army candidates,

1 This IVar Office letter and the reply thereto by the Civil Service Commissioners is given in Appendix $I$. 
and the mathematical training required for the Qualifying Examination is in marked contrast to that required for the Army Entrance Examinations. The questions set in the subject mathematics in the Army Qualifying Examinations are, for the most part, extremely artificial and deoretical in character, while the practical side, which was intended to be the prominent feature, is most conspicuous by its absence. While the Army Entrance Examinations (that is, those conducted by the Civil Service Commissioners) have set the pace in the teaching of elementary mathematics, the Army Qualifying Examinations either ignore this development or show no appreciation of its purport. It is surely time that a little more continuity were introduced into these examinations." There is something very comical in this criticism; the author is apparently unaware that it is the Army Council which is conducting this Qualifying Examination. If his views are correct, he shows that the Army Council lacks the practical experience to give effect to its own decisions; while the Civil Service Commissioners, who have been set aside to make room for other advisers, are seen to be well in the forefront, setting the pace in the direction the Army Council itself desires, but is apparently unable, to do. I would ask you to specially notice this situation as an illustration of a system to which I shall later invite your attention. The Civil Service Commissioners, the great expert and specialist body in all that concerns the conduct of public examinations of the State are set on one side to make room for newlyconstituted bodies which can lay no claim to approach the unrivalled knowledge and experience possessed by the Civil Service Commissioners. ${ }^{1}$

Lastly and briefly I must call to your attention the numbers annually required to fill existing vacancies. These numbers vary considerably in different years, but at the time of the Sandhurst Committee, 1899, the estimate was 500 per annum, in I 901 , at the time of the Akers-Douglas Committee, the number quoted was 800 . Of the numbers required at the time of the Sandhurst Committee the Woolwich and Sandhurst establishments could only provide for 350 , the remaining iso had to be obtained elsewhere. You must bear this in mind when you judge of the educational attainments of the Army officer. It is not a good policy for the State to be at pains in demanding high educational attainments from a portion only of those who recruit

1 The lecturer here pointed out that the authority immediately responsible for the Qualifying Examination was the Qualifying Board. 'This body is formed by delegates from those educational bodies authorised to grant "leaving" certificates, under the Presidency of Sir Henry Craik, who is also a member of the Advisory Board. The Qualifying Board are, however, strictly hound by the syllabus which has been drawn up by the Advisory Board. The Advisory Board, if referred to, say that the Qualifying Board are responsible for the examination; the latter, when ap. proached, state that their hands are bound by the Advisory Board. 
the officer corps. It must provide the means for the proper education of all. This, I understand, has now been done; the accommodation at Woolwich and Sandhurst has been largely increased, and it is, I believe, the intention to obtain the balance of what these institutions cannot provide from the Universities. But this is the result of the South African War. At the time of the war contempt and ridicule were heaped on the officer of the Regular Army by the British public most unjustly, and the memory of it still rankles. The Regular officer, and for that matter the Regular soldier, as little merited the public scorn as did his predecessors a hundred years ago, and the observation made by Sir William Napier is as applicable to the present time as it was in the past: "very subject to false impressions are the English; and being proud of their credulity as if it were a virtue, they cling to error with a tenacity proportioned to its grossness."

\section{Prospects of the Officer's Career.}

I now turn to the consideration of the prospects of an officer in the Army. This portion of our subject falls under two heads : the military aspect and the monetary aspect. I take the latter aspect first, and come to the question of pay: I will not dwell on details; you will find given in a tabulated form the various rates of pay for the different ranks of the regimental officer, together with the scale of pension.

In the Army at the present time the opinion is strongly held that the pay in insufficient. The first step in the examination of this question is to fix a standard. I submit for your consideration that formulated by Von der Goltz: "An existence free from care-yet no more than this-should be secured to officers by the State in its own interest." You have next to consider the average means of the youth you desire to attract to the Service, together with the expenses of that social status it is desired that he should keep up in the Service. Investigate existing conditions. Certainly a young officer cannot meet the expenses of his position on his pay. The addition to this pay which he requires in order to live free from care will be found to vary considerably according to that branch of the Service and the regiment in which this young officer is to live. Leaving out of consideration those regiments in which expenses are known to be high, and confining our attention to the infantry, the important part because of the large numbers affected, the case is not overstated; if the sum of $f$, 00 a year is fixed as the amount over and above his pay which the young officer must possess in order to live free from care. We thus arrive at the sum of $\mathcal{E} 200$ a year as the minimum cost of living in a British infantry regiment. Is this scale of living too high or not?. The public will certainly have a voice in this decision. Those who consider it too high must state by how much. The extent to 
which the State fails to meet its obligations in its own interest can then be determined in the case of the young officer. The case of the higher ranks needs, of course, similar consideration.

We have seen that the State has clearly defined the source of supply it desires to tap: "A youth who has received a liberal education as an English gentleman"; in other words, the youth educated at "schools of a public character giving secondary education!" The parent, then, of a youth so educated, who puts his son into a British infantry regiment, must, we see, be prepared to allow his son from $f 100$ to $\ell_{75}$ a year until his son attains the rank of captain. If the allowance then ceases, the son is no richer than the day he first joined the Service, and he receives no addition to his income till he reaches the rank of major. The prospect for the son is not too encouraging; but what about the parent? Does not the average parent who educates his sons at our public schools and universities find the expense of education a severe tax, more especially if his family is a large one? Does he not look forward to a time limit, to the day when the son is in a position to support himself? Is this average parent in a position to incur the expenses of placing his son in a British infantry regiment? As you answer these questions so you will decide whether the declaration of the State as to its source of supply of officers is true or misleading, and whether its intention would not be more accurately described by the words: "A youth who has received a liberal education as an English gentleman possessed of a private income of not less than $f$ ioo a year."

A comfortable theory, characteristic of British public opinion, exists that it does not matter what you pay your officers, you will always be able to get what you want. This idea is based on the fact that the fascination of the profession of arms, the brilliant vistas "which its pursuit discloses to honourable ambition, will attract all that is best and noblest in the youth of a nation. But this condition presupposes that insuperable difficulties are not opposed. Examine existing conditions. Take the case of the cavalry, in many ways the most attractive branch of the service. Speaking generally, no competition exists for commissions in British cavalry regiments. Turn to India, you find the situation completely, reversed: competition for appointment in the Indian cavalry is very keen. Look at the lists of cadets passing out of Sandhurst, you cannot fail to be struck at the large numbers of cadets who secure a high place, who elect to serve in the Indian Army.

Again, are there not many who accept commissions in British infantry regiments merely with the object of using such regiments as stepping stones to certain better paid but less martial corps and departments, who draw their supply of officers from: within the Army? Is it not clear that insufficiency of pay, at the present time most prejudicially, affects the British cavalry and the British infantry. It is a fallacy to suppose that it does not matter what is paid to the officer-it is 
correct what Von der Goltz has written, that it is to the interest of the State to secure to its officers freedom from care.

Peculiar emphasis is placed on the situation by the fact that quite recently the Indian Government has substantially increased the pay of officers in the Indian Army. It is also important to remember that public opinion has insisted that the officer should look on his career as a serious profession.

Formerly the law of compensation prevailed. If the officer was poorly paid he had the advantage of some leisure: This compensation he no longer possesses. The officer now works hard, and he looks on his profession with more of a business eye than heretofore. He now expects the State to more nearly requite him for his labours, and to abate in some measure its demand that he should pay for the high privilege of serving it, as he so long and thanklessly has done.

It has been suggested that present difficulties would be resolved if the pay of the junior ranks were increased by a corresponding reduction in the emoluments of the higher ranks. To those so minded I would recall to recollection the recently published remarks of General Sir Henry Brackenbury, where he writes as follows:- "I doubt if it is realised by the public generally how great are the difficulties of a military career to an officer who is not possessed of private means. It would have been impossible for me to take a Major-General's command at home or in the Colonies; involving, as it would have done, furnishing a large house, buying horses and carriages, and setting up an expensive establishment for a maximum of five years." Very significant are those words "or in the Colonies" - Colonial allowances are often but a bare pittance.

I pass now to the consideration of the military prospects of an officer's career. There are four ladders by which the young officer may mount to secure those prizes offered by the military profession. First, you have the ladder which belongs to the Staff of the Army; then the ladder of travel and adventure offered by Colonial employment; next, the scientific ladder which leads to the manufacturing department; while lastly there is the regimental ladder, which, so far as the ideal is concerned, should specially commend itself to those ambitious of becoming leaders of men. If in imagination you could descry all young ambitious officers setting out to mount the ladder of their choice, how niany would be found congregated round the regimental ladder? Thirty years ago keen young officers were advised if they wanted to get on in the Service to devote themselves to their regimental work and seek to be well reported on by their commanding officer. This advice needs qualification at the present time. If a young officer is ambitious he must $\mathrm{g}^{\prime \prime}$ to the Staff College or obtain Colonial employment; his prospects will be bad no matter. how able a regimental officer he becomes if he elects to stay in his regiment. To advance in the Service he must leave his regiment. It is thus seen that military and 
financial considerations both lead him away from his regiment. The seriousness of the existence of such conditions cannot be over-estimated. It is the regimental officer who has to fill the most trying situation in life-namely, in the face of death, called on to lead a mass of men and still preserve influence over them. The regiment is the school in which the leaders of men are best trained; it is a fatal error to allow the career of the regimental officer to suffer disparagement, for when war breaks out it is the regimental officer who bears the heat and burden of the day. The tendency of modern warfare is to place the issue of the battle, and thereby the fate of the nation, more and more in the hands of the squadron leader and company commander.

The door is now held widely open by which officers of educational attainments, combined with soldierly qualifications, can secure access to the ladder of Staff employment. Recent changes have greatly improved the prospects of Staff officers : the recognition of merit and the advancement of deserving Staff officers has been somewhat loudly proclaimed, but the means afforded to carry intent into practice, as is not unusual, seem inadequate, while some of the measures adopted seem to prejudicially affect the interests of the regimental officer. An element of uncertainty has been added which does not produce a general feeling of contentment.

Officers who obtain Colonial employment frequently secure the good fortune of seeing active service. The conditions of life are frequently hazardous, nearly always trying, but the opportunities for distinction are great. Officers who secure such appointments have good prospects. Such often in later years return to their-regiments, where they prejudicially affect the careers of their brother officers. The element of uncertainty is again introduced with its attending ills.

Officers of scientific attainments who desire to specialise in that direction will find the Ordnance College and the manufacturing departments in all respects a favourable field for their labours.

\section{Realisation.}

Such, briefly, are the prospects of an officer's career. What, we now ask, are its realities? If you go out into the Army will you find that a spirit of contentment pervades the body of officers? A very striking prediction in this connection was made upwards' of 'six years ago by Lord Wolseley in his memorable speech in the House of Lords. He then said: "I have been told that the new proposals were based upon a system under which the Navy'is administered by a Board. Not being a sailor I am incapable of expressing any useful opinion upon the system upon which our Navy is managed. I emphatically pronounce it to be entirely unsuited when applied to the government of the Army, and that under it you will never have an efficient, and I doubt much if you will ever have a contented, one." What did the officers of the Army lose when the new 
changes were introduced? They lost practically all that delicate structure which promotes the sentiment of high ideals and which opposes egotism - a work brought to a high state of perfection by His Royal Highness the late Duke of Cambridge-a work too little known and appreciated by the British public. It would be quite easy to particularise, but I will only instance the loss of the right of approach through the Military Secretary direct to the Commander-in-Chief, which was the cherished privilege of any officer however insignificant. Such an officer, if his cause was just, was assured of full redress, no matter how potent the forces arrayed against him. I submit that, save in extremely rare cases, Royalty alone can give that complete assurance of protection which is necessary. Such, I believe, was the opinion of the Duke of Wellington.

We have noticed certain instances of an element of uncertainty being. introduced into an officer's career. This feature of uncertainty is most pronounced at the present time, and is largely promoted by Army. policy and the Army system. There is no continuity in Army policy; one year the establishment is increased, another year it is decreased; the changes produce anxieties and induce a general sense of uncertainty. The Army system is not a new growth, but some of its characteristics have been more prominent in present years than for some time past. The British officer is expected to fill efficiently any post to which he is appointed, whether he possesses any previous experience in the duties he is called on to perform or not. Please do not misunderstand me-disabuse your mind of the personal elementrivet your attention wholly on the system. Our Army system virtually abhors the specialist and the expert - such is the logical inference to be drawn from an article by a well-known authority who has filled a very highly placed post on the General Staff. I refer to Colonel Callwell's article on the General Staff in the January number of the National Defence MIagasine, where the states that specialists and experts are not wanted on the General Staff. As an instance, I quote the case of those officers who, having devoted themselves entirely to the study of Coast Defence Warfare, not infrequently find in the General Staff officer appointed to instruct and prepare them for war, an officer who may never have served in a coast fortress before. Our system aims at securing an able officer and employing him under widely varying conditions and circumstances rather than restricting his employment to that particular sphere in which he displays marked ability, and there developing his talents to the full in the public: service.

What would have been the result had Prussia adopted such a) system? Can we seriously contemplate the adoption by Prussia of a system the result of which might have seen that Power opening the war of 1870 with Moltke and Von Roon commanding the Ist and 2nd Armies, Prince Frederick Charles controlling the Administration, and Steinmetz Chief of the General Staff? Yet some changes of this nature must inevitably 
have been imposed by our Army system.... The converse is equally pertinent. In the British Service, Moltke could never have created for you a General Staff; neithèr would Von:Roon ever have been able to make the British Army the wonderful machine for war which he didithe Prussian Army, even if political conditions had been favourable.

This system may have advantages, but amongst its disadvantages is that one which produces general uncertainty in an officer's prospects. Let an officer work as hard as he can; let him qualify himself in every way possible; let him win the approbation of those under whom-he serves; nay, let him win much distinction: he never knows-when -his prospects may not be blighted, not because he is not recognised as deserving, but because someone drops, as it were, from the clouds and has to be provided for. There is also another great disadvantage : the officer does not understand the raison d'être of the system, and those who are unaffected as well as those affected view the situation with apprehension.

In our study of this subject we can find no sign of any diminution of martial ardour in the educated youth of the nation; but we do find a istate of affairs subsisting which dissuades it from entering the ${ }^{1}$ British service. While within the Army we find conditions which tend to produce a somewhat widespread disappointment of the reasonable expectations of those who have embraced the noblest of all professions

TABLE OF REGIMENTAL PAY AND PENSION SCALE.

From the Article by "Reserve" in the "National Defence Magasine," July, rgog.

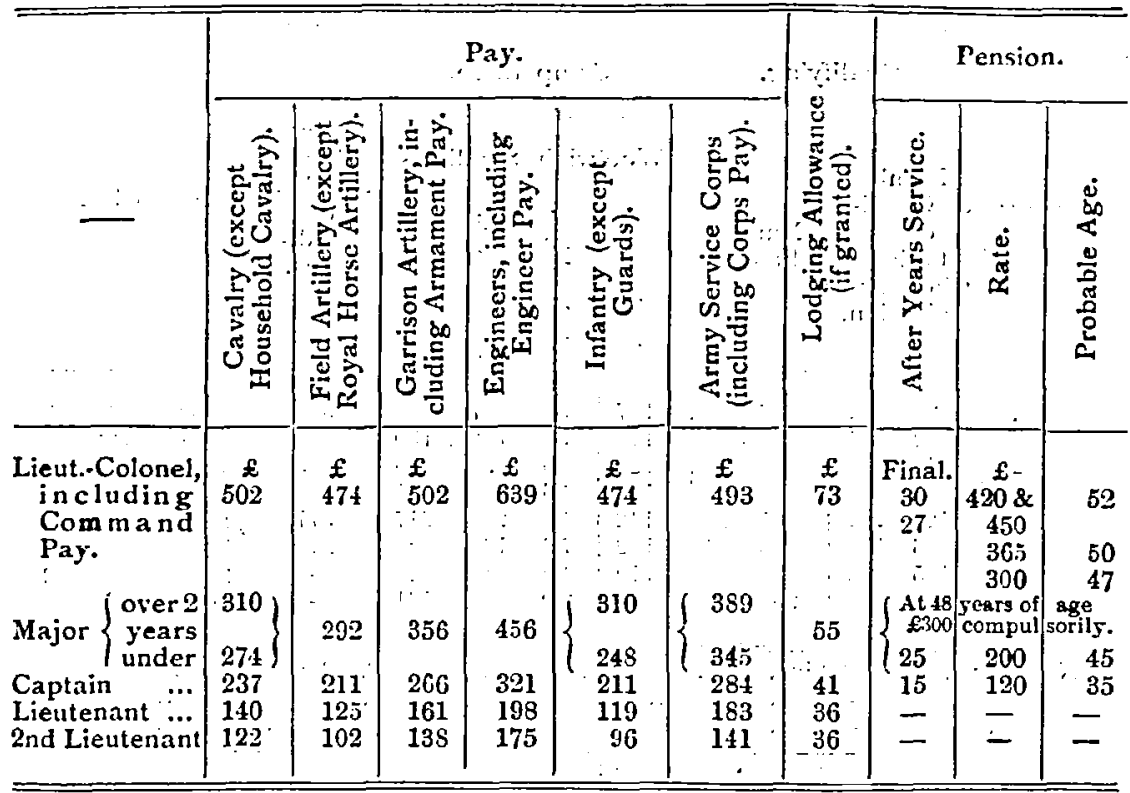

VOL. LIV. 
STATISTICS OF. EXAMINATIONS FOR:ADMISSION:TO WOOLWICH iin $\therefore$ AND SANDHURST.

Compiled from Reports of Civil Service Commissioners and Official Publications, giving Results of Examinations.

OLD,SÝstem.

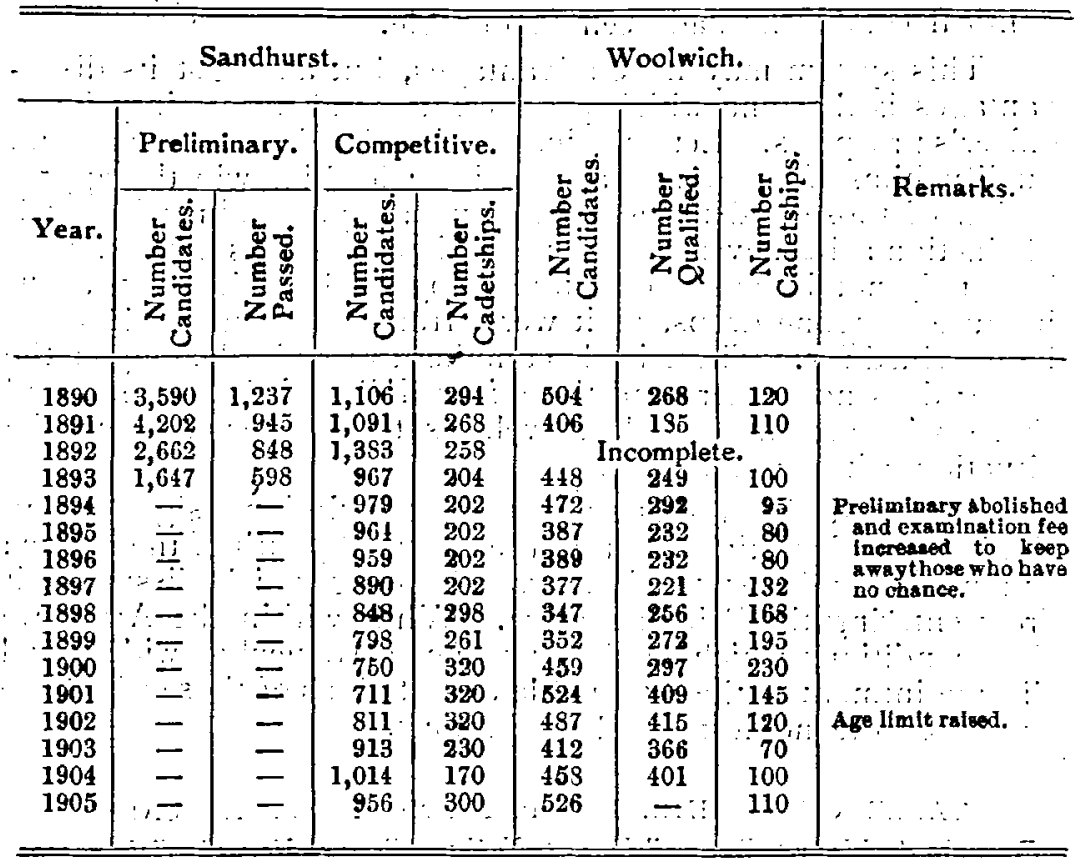

New System.

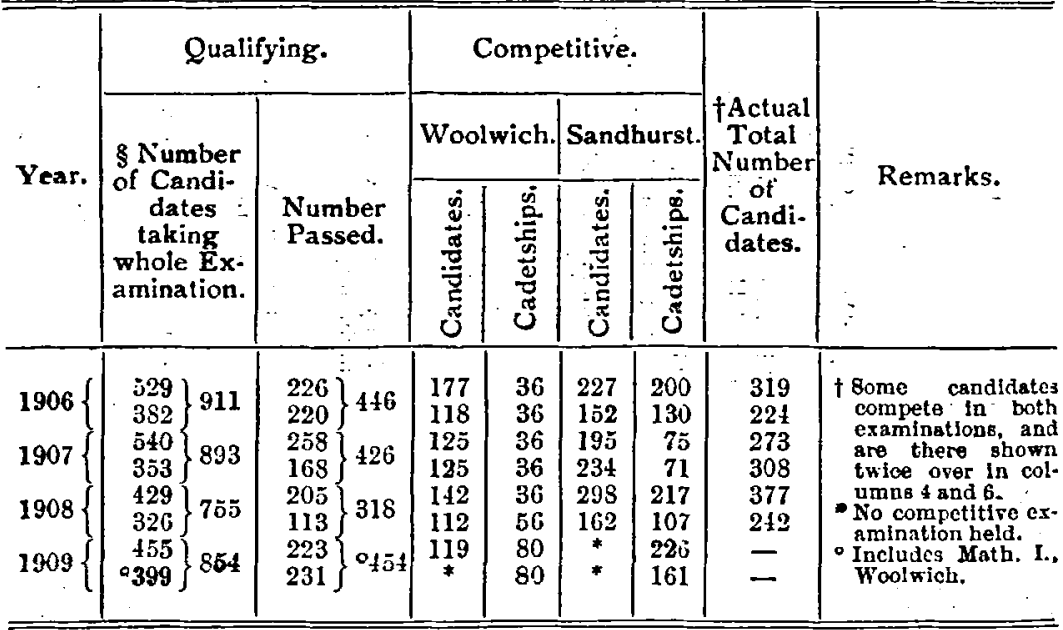

Note for yrs. 1894.99 inc. Av. ann. No. Candidates 1293. Av. No. Cadetships 352 .

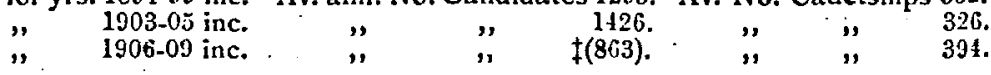

1 This does not Include Candidates with Learing Certificates.

if total number of candidates presenting themsclres be taken the arerage $p . a$. will be 925 , but this figure would Include many taking "leaving" certilicates. 
THE ARMY AS A PROFESSION.

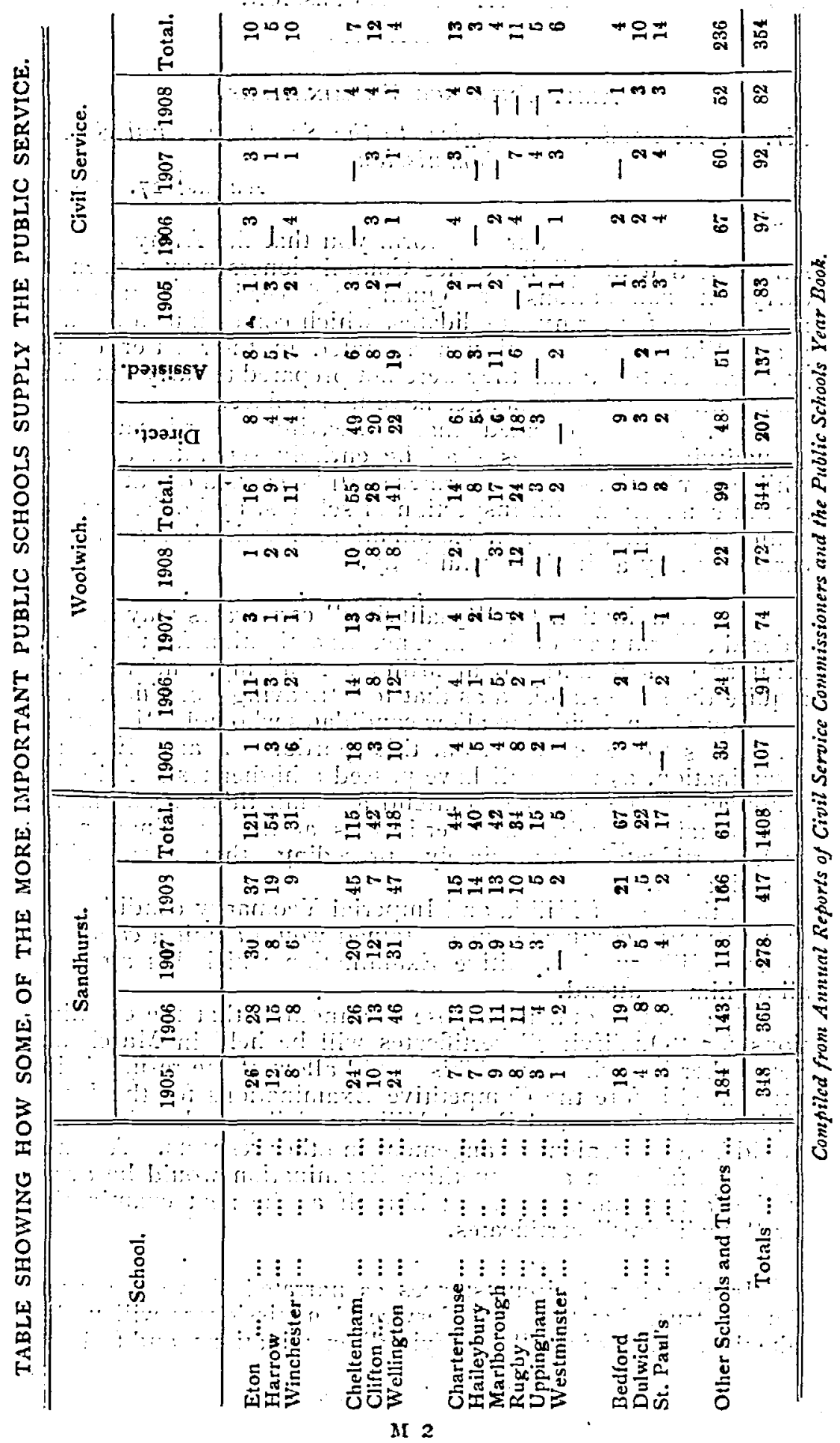




\title{
APPENDIX.
}

\section{ARMY ENTRANCE Examinations.}

\author{
Mr. R. H. Brade, War Office, to the Secretary, Civil Service \\ Commission.
}

Sir, -

$$
\text { August:27, 1904. }
$$

$I$ have the honour to inform you that the Army Council still hope that the Civil Service Commissioners may consent to carry out examinations for "Qualifying" certificates under the new scheme for Army Candidates, which comes into force next year. Since the Commissioners stated in their letter of the 3 rd October, $1903,{ }^{1}$ that they were not prepared to carry out these examinations, several changes have taken place.

"It has been decided that "Leaving" certificates and "Qualifying" certificates shall be entirely separate; and that while examinations for the former shall be carried out at schools and in connection with inspection of schools, by bodies directly connected with education, examinations for the latter shall be carried out by a single central body.

;The examination for:"Qualifying" certificates may be"con-" sidered to form part of the Entrance Examination for the Royal Military College and Royal Military Academy, and need not require the same standard as that for "Leaving" certificates.

It has been decided to allow candidates who hold "Leaving". certificates to be exempt from this portion of any Entrance Examination, as they will have passed a higher test. All other candidates to be eligible to attend a Competitive Examination must obtain "Qualifying" certificates at the examination for. such certificates immediately preceding - that Competitive Examination."

In the case of Militia and Imperial Yeomanry candidates, a "Qualifying.' certificate once obtained would admit a candidate to any Military Competitive Examination which his age may allow him to attend.

The Army Council propose to announce that the examinations for "Qualifying" certificates will be held in March and September in each year. This would allow of the results being announced before the Competitive Examinations for the Royal Military Academy and Royal Military College take place, and would be a convenient arrangement in other respects. A candidate who failed in a Competitive Examination would be aware. of the fact in time to present himself at the next examination for. "Qualifying" certificates.

In the altered circumstances as narrated above the Army Council trust that the Civil Service Commissioners will undertake the conduct of the "Qualifying" examinations, and feel sure

1 Not printed here. 
that the announcement that they will do: so, will cause universal satisfaction.

$$
\text { I am, \&:c. }
$$

The Secretary,; Civil Service: Commission; : to : the : Secretary, War:Office:

SIR,

September, $26 ; 1904$.

With 'reference to $\mathrm{Mr}$. Brade's letter of the' 27 th ultimo, I am directed by the Civil Service Commisgioners to assure you; for the information of the Army Council, of their desire to cooperate so far as possible with your-Department in all matters which fall within their province, but at the same time to express their regret that it is impossible for them to accede to the request that they should undertake the conduct of the examination's for "Qualifying". certificatés."

In this connection $\mathrm{I}$ am to call your attention to Mr. Howlett's letter of 3 id October, $1903,{ }^{11}$ and to point out that in the first and second paragraphs of that letter the view of the Commissioners is expressed that their functions as advisers to the War Office with regard to educational tests and examinations under the Order in Council of 26th February, 1897, are now restricted to the scope of the competitive examination and to questions directly connected therewith. Moreover, I am to refer. you to Section II. in the same letter, which gives the reasons of the Commissioners for holding that the conduct of such a "Qualifying" examination should be entrusted to an educational body. The Commissioners adhere to the opinions then expressed, and they do not see that any new dircumstances have arisen to induce them to change them. I am also to remind you that the Commissioners were informed by a letter from your Department dated I 2 th January, $1904,{ }^{2}$ that the Advisory Board on Military Education themselves accepted the responsibility of arranging for carrying out the "Qualifying" examinations, and that Mr. Arnold-Forster had a aproved of this recommiendation.

With reference to the suggestion that the same standard need not be required for "Qualifying" certificates as for "Leaving" certificates, the Commissioners still adhere to the recommendation conveyed in the letter from this Department of $3^{\text {rd }}$ October, $1903 ;$, that the same "Qualifying" examination should be required of all candidates. The effect of adopting two different standards of examination, of which the "Qualifying" standard should be the lower, would, in the opinion of the Commissioners, be to encourage the weakest candidates to leave the schools and have recourse to private tutors to be prepared for the lower examination, and that, in general, the weaker and

1 Not printed here:

2 Printed in the Appendix to the 48 th Report of the Civil Service Commissioners. 
idler boys would gravitate to the lower examination, and thus defeat the object which the Army Council no doubt have in view.

The Commissioners agree with the Army Council in holding that if a "Qualifying" examination were held independently by all bodies mentioned:in paragraph 5 of the paper headed "Commissions in the Army," inconyeniences, and in particular, differences - of standard, would probably arise; but they see no reason why, if the examiners' fees are paid, the Oxford and Cambridge-Schools - Examination -Board, for England, the Scottish Education Department for Scotland, and some similar body for Ireland, should not examine candidates for the "Qualifying" certificate at the same time and on the same papers as candidates for the "Leaving" " certificates: The Civil Service Commissioners in holding their own Army Competitive Examinations at local centres make it a stipulation that candidates from outside who wish to be examined shall be admitted to the schools for that purpose... If, however, the Army Council meet with initial difficulties in negotiating with the various educational bodies, the Commissioners would suggest that the existing system of examination which appears from the results to be very successful in securing the objects for which it was designed, should be continued for another year::i

\section{I have, \&c.}

Lieut.-General H. D. Hutchinson, C.S.I.:-I am sure we are all agreed that Major Churchill has given us a most excelient lecture on a most important subject. It is an essential condition of a good lecture that it should be not merely interesting. but also full of food for profitable reflection. That condition'is; I think, amply ifulfilled by Major Churchill's discourse. He has given us plenty to think-about. I am therefore glad to see a very large attendance here this afternoon. It is significant of the great interest taken in the subject of the lecture; and as I observe many present who are well qualified to give us sound views and useful suggestions on the points which have been raised, I hope we shall have a very interesting and profitable discussion.

I should like to say, before I 'speak on the subject before us, that I feel sure that everyone here understands that neither is this lecture, nor any lecture delivered under the aegis of the Royal United Service. Institution, given with any idea of indulging in carping criticism or captious fault finding. The sole object with which the Council (of which, at present, I have the honour to be the Chairman) organises these lectures and discussions is to help. to encourage, and, if possible, to instruct; to throw light on knotty questions and tangled problems, and so to assist in solving and unravelling them. And it is in that spirit; I hope, that all who are:so good as to take part in the discuission this afternoon will approach the subject. And now, 'Sir, to the point. The salient fact which we' have before usmomentous fact which cannot be evaded, and must be met-is that the Army as a profession is not popular at the present time. Opinion on this point cannot be divided, for it is quite certain that the candidates required to fill the vacancies in the commissioned ranks are not forthcoming in anything like sufficient numbers; and further, that the supply,

1 Not printed here. 
such as it is, is decreasing, and has been steadily decreasing for some years past. 'There are many, in this room; who, like nyself, can remember the years of plenty, when there used to be an average of eight or ten candidates for every vacancy at : Sandhurst or Woolwich. Now : the vacancies are more numerous than the candidates, and, even for the Artillery and Engineers, candidates are now about to be admitted to the Royal Military Academy-for 'the frst time, I believe; in its historywithout undergoing the usual Competitive Entrance Examination. What can be the reason of this unfortunate condition of things? The lecturer has dwelt: for some length on the Education question-the dificulty and uncertainty attending :the Qualifying Examinations, and so on. That may have something to say to it. I will refer to this matter presently. But in my. judgment the deterrent effects of examinations are insignificant compared with what I would call the two prime causes which in these days make parents and guardians and candidates look askance at the Army as a profession. 'These are, first, the inadequate rates of pay of subalterns and captains : and; second, the uncertain prospect of an officer's career:in the British Service. On these three points, examinations, pay, and prospects, 1 should like to say a few words if you will have patience with me.

Mäy I: preface my remarks by saying that I believe we shall best appreciate the difficulties of the problem before us if we try to bear in mind that it is the regimental officer who is chiefly affected by them. It is the regimental officer who is the backbone and substance of the Army. If it is admitted that the Army as a profession does not at the present time attract icandidates, and that reforms are necessary, then I submit it is from the point of view of the regimental officer that reforms should be considered. : He is certainly the most important unit of the commissioned grades in the Army: One icould conceivably: get on without, say, a Brigade-Major, but you could not get on without the regimental officer; and if substantial improvements (which I believe he thoroughly deserves) could be effected in his position and prospects, I am sure the Army as a profession would soon recover its popularity, and we should hear no more about a shortage of officers.

And now I would say a word about the Army Entrance Examinations, which, as at present conducted, are apparently considered, in some quarters, to be unduly difficult, and to have the effect of discouraging and frightening away candidates. The lecturer has gone into this matter in some detail, and has taken' me rather out of my depth. I think in describing how the present system has come about and is worked, and in his allotment of responsibility to various bodies, he is in error in one or two points, but these are of minor importance. What is really of consequence is the results; and although $I$. myself was in office when the present system was introduced, I must admit they, cannot be described yet as wholly satisfactory.: But I: do not believe, that anyone really' thinks that the standard of education fixed for Army candidates by the Leaving and Qualifying. Certificates is a too-high standard. Judging, however; by results, and by reports that one hears, I think there must be room for some improvement in the way in which the Examinations are carried out. I have had some considerable experience in carrying out and controlling examinations, and I can testify that it is a very difficult thing to find a good examiner. An examiner can easily keep. within the four corners of a syllabus, and yet set: $a$ very unsatisfactory paper: I am sure all those officers who have been associated with me in my work will endorse that statement. There is no lack, I need hardly say, of extremely able and clever men, but it is notorious that the cleverest men do not by 
any means make the best examiners. I know that in the War. Office, I although we exercised a very close and vigilant control over. examiners' work, we did not always succeed in satisfying examinees, or in aroiding occasional sharp criticism. But still the careful scrutiny and supervision of the papers, set had on the whole the best effect, and I suggest that it is in this direction that some improvement, might be made in the conduct of the Army Qualifying and Leaving Examinations, and thereby :greater confidence in them created.

I pass to the question of the pay of officers.... This is purely a matter for the . Treasury, : for I do not believe there is anyone connected with the Army in any capacity, from the highest to the lowest grade, who honestly!believes that captains and subalterns receive an adequate remuneration for their services. Therefore, if the Treasury could be persuaded to make, the necessary grant, it would certainly have the approval and the blessing of all concerned. It inust be remembered that the class which chiefly sends its'sons into the Army is not, and has never been, a rich class; : and in these days of high rates, heavy : taxes, and increased cost of living, the pinch of a small and inelastic : income is more felt than ever.: Therefore, it is a hard matter for parents to give a boy a long and expensive education,. and afterwards, when he has got his commission, : to make him an allowance for an uncertain period, until he can manage on his pay alone. $\because$ It must also be borne. in mind that in these days the regimental officer iworks very hard, and I will say, very cheerfully, for the' small : pay that he

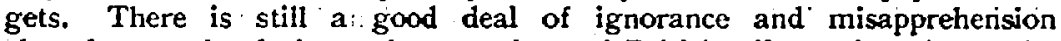
abroad as to the duties and occupations of British officers, but those who know, know that his work' is strenuous and continuous, and that whether he likes it or: not he has to "scorn delights and live laborious days." No servant of the State earns his pay better than. he does, and I am convinced that it is full time that the State recognised his worth and remunerated him accordingly. I would point out that the disadvantageous position of the British regimental officer is emphasised and accentuated by any comparison with that of his brother officer : serving in the Indian Army. In that-fine service which offers so many, good openings to the keen soldier, the regimental officer receives pay on which he can live corrifortably from the day on which he joins; his promotion, step by step, is assured, and does not depend upon accidents, as does that of the officer in the British Service under the regimental system; and in due fulness of time he knows he will get a good pensionprovided always that the Bengali Baboo does not turn us out of India! What is the consequence, the very natural consequence? It/is that there is never any shortage of candidates for the Indian Army: They get the pick of every batch that comes out of Sandhurst; and there is probably not. a British regiment in the Service which does not contain youngsters' at this moment who are chafing to join the Indian Army, because of the independence which they will gain by doing, so. I do believe this question of sufficient pay-or perhaps I should say, insufficient pay-to be the bedrock of this problem of the supply of: officers, and I am convinced that if the case of regimental officers of British regiments were to be taken up by the Government, as Lord Kitchener and the Vicenoy, and the Secretary of State for India; lately took up the case of officers of the 'Indian Army, their action would be not only lauded as generous, but also would be universally acclaimed as just and wise.

In conclusion, one word as to the uncertainty of the prospects of officers. This is a matter in which legislation is very difficult, "and it is 'not easy to suggest any remedy.' But that the uncertainty exists is certain, and 
also that: it is a potent factor. in creating : dissatisfaction, and in sapping the sources of supply of officers to : the Army. If this fact were fully recognised and appreciated at Headquarters, that by itself would be a step towards improvement: It is a very risky thing for an officer to let off a grumble, or to be known as a man with a grievance. Therefore, officers very wisely and properly, and I may say loyally, do not "talk" with rare exceptions. Still, it is undeniable that there is a great deal of uncertainty. during an officer's career as to his position and prospects : and this uncertainty' has a bad effect, which is enhanced by the blows and disappointments $;$ which sometimes, fall; because these are often felt to be undeserved. $;$ I may mention one instance of the kind of thing that happens. Until quite recently an officer.'had to go at the age of forty-eight, unless-he had by that time reached the rank of :LieutenantColonel.. The other day this age limit was altered to fifty. $\because$ That saved and pleased a few officers, but it disappointed many more than it pleased, and it unexpectedly retarded for two years the promotion of a great many. I do not criticise the new order; I only remark on its effect; as creating uncertainty and disappointment, and in some cases unmerited hardship.

I could say a great deal more, but I have already exceeded my time and trespassed on the limits of your, patience. I will only add that in spite of ${ }_{i}$ all drawbacks and! disabilities there can : be no doubt that the Army as a profession is still the finest opening in the world for anyone. I thank you for your attentive : hearing.

Major E. C. HAwksiaw, R.A. (retired) :-I feel extremely diffident in rising to speak in the presence of so many distinguished officers senior to myself, and only do so because I . think some good : may accrue. Why is it that the Army is unpopular as a profession now? It is an unpleasant fact to contemplate, but. there it is! The profession of arms, until recent years the noblest aspiration that youth rould have, and once so popular, is now shunned. In my mind the reason is simple, viz., the present system of Confidential Reports. I grant you must have them in some form, but, in all honour and fairness, not as they are now: May I here mention the fact: that the great General Gordon was once reported by a superior as unlikely ever to make an efficient officer!. Let me give another instance, which will scarcely. be credited, and which "will show better than any words how earnestly invoked by the speaker is the day when we shall once more have a Royal Duke at the head of the Army. When the late Duke of Cambridge was : retiring from the post of Commander-in-Chief, and Lord Wolseley was taking his place, the great innovation of fire discipline was being rightly pushed hard in the practice camps of the Royal Artillery. I was serving in command of a battery in India at the time. Well; the orders for carrying out this practice were, I can only say, childish and ludicrous, and their adoption led to most of the grief, in loss of 'guns, etc., which befel the R.A. in South Africa. An officer of, my acquaintance' wrote pointing this out, and advocating reforms. 'He incurred the wrath' of the authotities, and was told to send in his papers. He appealed to the Duke, who ordered him back to duty 1 . When the Duke went he was ordered again to send in his papers by the Commander-in-Chief, but stoutly refused to do so, asking for a Court. Martial or Court of Inquiry, both of which : were refused, and he then found himself gazetted out, no reason for the action taken against him being vouchsafed...: He tried; legal efforts at - redress, and his solicitor was told i by a a high IVar.. Office : authority that 
there was no case against him at all (quite true)... He :appealed in every way allowed by the Queen's.Regulations, and invariably came the answer back :.."This case cannot be re-opened." $\because$ Many reforms that he adrocated have now : been adopted, but his career has, : of course, been blasted for ever. Any names required I can give. Now is such an abuse of. justice as this likely to attract youngsters to join a profession where at any moment, for no fault, they may be ruined? In the R.A. I had the advantage of serving in the R.H.A.; R.F.A., and R.G.A: under the old system, and have no words in which to advocate the present system of Confidential Reports, having witnessed their working in England, India, and the Colonies. The remedy that I would suggest is that any officer who thinks himself aggrieved should have:the right to a court of inquiry, or a court martial, or, better still, an appeal to a civil court of law. We shall then have some protection which at present we have not; as I have shown, appealing exists in theory alone.: I have seen during my service men whose high rank authorised them to be entrusted with the compilation of these reports, whose sole claim to distinction and position seems to have been that they were possessed of qualities which were the last that any officer should possess, and yet there were' no means. of challenging their decisions or of having these revised by some other impartial authority. I trust that what has heen brought forward may impress my hearers that nobody knows, except those who have been in the Army and had experience of all that I. have said, what a blot on. our system these reports can be made. I am convinced that a prompt change-madepublic-would much help in the addition to the number of candidates for what should stand, and did in old days, as a privilege-the holding of a commission in the Army, to serve our King and country.

T. Miller Maguire, M.A., LL.D. (Barrister-at-Law, Inner Temple) : -In response to your challenge, my Lord, I must let some of my ammunition off, however unpleasant it may be to a considerable portion of the audience; but I wish to support in the strongest possible manner the protest that has just been made by Major Hawkshaw against what.I consider is : a fatal disgrace to: any profession, particularly the noble profession about which the gallant lecturer has been. speaking. I entirely agree with every word the latter has said about the Profession of Arms. . Not only has he quoted immortal lines. on that subject, but anyone who has the least knowledge of English literature, or general literature, such as was expected from every officer of the Army before the entrance course was modified to suit the absurd caprices of the worst schoolmasters in the world, namely, those of the fashionable English public schools, could go on : all night selecting examples $\because$ from the prose works of Ruskin, from the poetic works of Chaucer and Spenser, about chivalry and arms, knighthood and love, and from the records of Napier and Alison, not to mention the long line of ancient and foreign historians, to show that the Profession of Arms at large is, as Jeremy Taylor said, a noble thing. In one of his sermons the great divine: said: "I myself feel bound always to admire the courage of the soldier. Here is a poor, wretched person, badly clothed"'-as he was then-" who for a miserable consideration will walk coolly to death at the command of a sergeant." If a man that will walk coolly to death at the command of a sergeant was then worthy of being commemorated in immortal language by one of the greatest of our Ecclesiastics, what. about the man who preserves his brain-power in the midst of an inferno, and not only himself walks coolly to death, but leads others and helps others 
marching in the same direction? Nothing finer can be contemplated by the humar mind. There is nothing which has been.immortalised more often in poetry, from the heroes of Troy to the heroes of the most modern times. Having been brought up myself, if I may say so, : by a far-seeing, benevolent, and reverend father to admire soldiery," and having been connected with soldiery of all:ranks all my life, I reecho those elevating sentiments only too truly set forth by the lecturer. : But the oontrast between the sentiments of the lecturer and the facts that Major Hawkshaw has mentioned is abhorrent to any honourable man. If Jeremy Taylor's was the ideal view of the soldier, the 'ideal of the War Office is very different. Confidential reports! - dishonourable reports by any person in authority"against : a poor lieutenant or poor captain.' I have been the victim for many years of seeing with horror these Reports in my capacity as a lawyer. Report after report, confidential disgrace after confidential disgrace, has been put before me, and, as Major Hawkshaw says, there was no redress. The only legal advice was "a soldier has no legal rights" - an officer of our military services is only a legal pariah. There was no use in any solicitor taking up a soldier's case for any fee, small or great; defeat in our courts at the instance of Crown lawyers was a certainty. What kind of a career is that? No redress for ruin by an infamous report by your superior!. What is the law on the subject? I have quoted it again and again. You soldiers come down to the Temple with your case, and you think you can get redress. You will find that you can get none. The Grank Turk is nothing to the GrandI beg your pardon, Sir, I was going to say-the Grand Secretary of State for War, but that is ammunition too strong! I hope I may say in reference to party politics that officers of both Services are going to have soon, in consequence of the events of the last twenty-four hours, a better time in the future. "A series of new times" will begin for them, let us hope. As I cannot allude to the Secretary of. State for War perhaps I may give my own experience. I have been asked for, I should "think, a thousand confidential reports. I used to get regularly about one hundred times a year the following question, signed by a person in authority at the War Office. The question which used to be asked in connection with the young candidates for the Army and Militia officers was: "Is his moral character "-at the age of seventecn-" absolutely unexceptional." These confidential reports used habitually to come to me in a big envelope marked "Confidential," and I used to send my report back in a bigger envelope marked "Non-confidential Report." Think of asking a man like me about a young officer of seventeen to twenty years of age whether his moral character is absolutely unexceptionable. Mine was not-I would be very sorry indeed to have had a character anything like that. I would have lost a great deal of information that I have acquired if I had pretended to be anything of the kind. Is his moral character, absolutely unexceptionable? Perhaps so-1 hope not, was my reply: "At any rate it is just as good as Hannibal's or Cæarar's, or Napoleon's, or Nelson's, or that of Cabinet Ministers, or it must be pretty bad." Now did you ever hear such rubbish as this to pass for common sense in a wise nation? Confidential reports!-I wish I could read out my briefs when engaged in the cases of Army officers, to this audience, and I would make each perpendicular hair, not on you, my Lond, because you are an old Parliamentary hand; but on all the ladies in this audience, to stand on end, "like quills upon a fretful porcupine." In order that it may prevent any further difficulty being raised about these confidential rcports, I want to quote you the opinion set forth by the chief of the 
ofticial legal condottieri, to wit, the Attorney General. I do not: think "condottieri" $i$ is a bad word to use. When I use ithe word condottieri I compliment official lawyers, because among the Italian condottieri werc some of the ablest military brains in their age. The professional soldiery, German, Italian, Swiss, Scotch of the sixteenth and seventeenth centuries, who fought all over Europe, were among the most skilful soldiers in all history, and without skill and knowledge in war mere courage is a form of madness as Von Hoenig says.

\section{Colonel Stewart :-What about the Irish Brigade?}

Dr. Maguire :-My modesty prevented any allusion to the Hibernians, the lecturer referred to English rather than British, but I had a notion that the Scotto-Hibernian Colonel Stewart on my right would make up for my deficiency. The services of the Irish Brigade are writ large in the annals of French renown. The condottieri of Italy and the exiled Scotch, and Irish and. Huguenots were magnificent soldiers, but I am going to quote to you the opinion of a legal condottiere. Whom an I going to quote? His Majesty's Attorney General, Sir William Robson. Here is the legal position of the British officer. Are you content with it? Is there any certainty in it?. Is this a profession?. Is this a career? Are officers for ever to be victims of the shuffling tomfoolery of political partisans? At any rate this is what was stated by the Attorney General a short time ago to the Court of Appeal: "The commission is held entirely at the King's pleasure." Curious! Why is not a Judge's commission held entirely at the King's pleasure? Why? Is an Attorney General a more decent, a more useful and truthful person than a real General? He gets four times the pay; is he four times as good? Is he half as good? Is he rot a legal condotiete. mercenary paid for talking at the rate of twenty guineas a day all the year round, whether he talks or plays golf? He says that "an officer's commission is held entirely at the King's pleasure; His Majesty may dismiss with or without enquiry. He may select as the agents for the purpose of holding an enquiry any persons he likes," and "they may be called by the name of somebody else or by their own name.". That is the Court of Appeal for officers I "They may for the purpose be legally, or irregularly constituted I" In regard to officers there may be enquiry or no enquiry, but there can be no doubt as to the complete power of the King acting through any military authority " to dismiss without any particular cause shown, but merely at his pleasure." By this, in my opinion, highly disloyal phrase, the Attorney General means: "At: the pleasure of His Majesty's Secretary of State for Foreign Affairs." This Grank Turk, this Sublime Porte, may be an. Englishman, or an Irishman, or a Scotsman, or a K.C., with or without practice, or a man who has never even been a .Volunteer or a philosophic humanitarian, but by any kind of metaphysical or forensic General your real General Officers may be dismissed at their caprice, at the mere ipse dixit of Power. You have no appeal. A Field-Marshal or a Colour-Sergeant can be ejected without an hour's notice, or cause shown, and there is neither appeal or redress. A great deal has bern said about advisory boards and military councils. What on earth is the Educational Advisory Board. The Education Advisory Board consists, as it seems to me, and as Major Churchill says, of as curious and anomalous an assortment of ill-conditioned and ill-assorted atoms and accidents as the followers of Hudibras. The lecturer has : proved that everybody and anybixdy can be an examiner or an Advisory: Board potentate except a person who 
knows his business. As for the War Office edicational system,; it is a deadly Upas, an' all-blighting tree. I have had the terrible misfortune of being induced against: the warnings of all my frierids to waste twenty-five years of 'my life under the deadly Upas. I hate the Army Council with all my soulif and have never ceased to denounce it in an enormous variety of 'historical examples, and letters, and appeals, not one of which the Council read from the day it was founded till now. Its creation was the worst:: military nitistale that any party ever made in Englánd, and I sincerely hope, my Lord, that if in England, through a good Providence, the political "parties change, and others come in, "one 'of the ' first new phases of military policy may be to hark back to the common military sense of mankind and nominate a Commander-in.Chief." But I will not keep you longer on this subject, because I want to say something about examinations and public schools; and to give my own experience of the extraordinary thing. called an examination. Gentlemen 'have called the Qualifying Test a hard examination. A hard examination ! - Why, there would not be a public school or secondary school boy in Erigland of sound health and 'normal brain power, taught with any degree of efficiency, by clerical or lay teachers, in any kind of efficient class, that could not pass at ithe end of the tro years; between fifteen and seventeen "il twice as hard an "examination! "What ?about the 'German; of Japanese, or American' Standard, the minimum standard for officers? I reniember when the examinations were hard, when there was a proper Preliminary Ex-

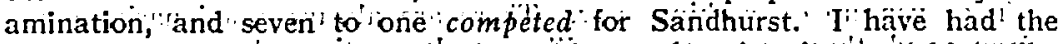
misfortune of being connected"with militäry education for something like twenty-five years.' "I was warned 'not to touch it with a pair 'of tongs'; but I' did, : and the tongs have not protected me or my poor oolleagues from War Office fires, and wave heen burnt most effectively: "It has been my fate to look into the intermediate education of other countries, and to deal with the secondary education of poor Irish lads, with not"a fraction of the advantages of Eton and Harrow lads, and there is not a single small shopkéeper's son or daughter bf sixteen either in Belfast i or Galwaýy, Cork' or 'Dublin, of average intelligence that could not pass with the greatest ease the qualifying examination. Why? Because their tutors and schoolmaster's are compelled by their fathers to look after the brains of their pupils betimes, and games are not put before learning. '. Knowledge is "worshipped by" "'poor Irish," Scotch, and "Japanese; English clerical fashionable schoolmasters "kill the very germs of intelligence." "When the richer English"are true to their' children's 'real in terests, and compel schoolmasters to " mend or end" there will be no more complaints of thè severity" of "childish "educational" programmes. $I^{\prime}$ am " sure the lecturer agres with me. One nord more on the Army Council question and the Army Board question. Even supposing you are able to prove that the Boards of the Navy are perfect, I have read that there was a Navy Board under Lord. Melville, of whom you have heard, Sir, in connection with Parliamentary impeachments, and that it did not know the meaning of sea water-that was years ago, in the year 18.13-and Wellington said: "Here is a Naval Board that absolutely does not know the first conditions of the element of which they have got charge." Naval Boards have failed in many instances. I have heard criticisms about curious Naval Boards in the last two or three years. But General Grant as well as Napoleon-one of the greatest of all militarists, possessing one of the soundest military heads that ever organised-and every other officer of ability all denounced the Army Councils system which has been foisted with reckless haste and ruinous consequences on 
our unfortunate officers. One of the most recent exponents of military literature and science is no less a person than the French General Langlois. I would not dare, being a mere civilian and a mere kind of mongrel of a lecturing lawyer and a volunteer, to put up my opinion on this matter as against the chiefs of the military world, but take what General Langlois says.:: General Hutchinson will admit that I could not make a better quotation in regard to the theory: of war in the last few years than from General Langlois, and he says: "A Grand Council or Advisory Board (educational or other) is only fit for deception.". Gentlemen of the Army and civilian taxpayers, if you like that deception stick to it. You pay your money and take your choice. "The'psychology of Boards and Councils is curious "- that of our Council is very curious indeed. "These are after all irresponsible assemblies." I noticed that in the House of Lords, when one case was being discussed, Lord Methuen said he was on the Board of Selection for the Army, but was absent in that instance, and the Duke of Connaught was somewhere else; also on the Board, but nobody is there when you want him.: It would not:pay to fix responsibility; it is an anonymous Board, whereas the Commander-inChief is tangible.: "These, are, after $r_{\text {, }}$ all, anonymous irresponsible assemblies, and pusillanimous to a degree," says General Langlois. I heard the late Mr. Arnold Forster say in the last speech he made in this Hall that the very. same Army Council folk had agreed to every single proposal of the Government, however different, contradictory, or absurd. "They venture on nothing new: There are always reactionaries among them, and there are mere cavillers and sceptics who are even more dangerous than the progresseries at any cost." : The votes of such a lody are quite worthless. "." Its solutions are hesitating, and only, tend to a statu quo." "There is nothing manly; nothing original about its decisions. May I, Sir, as a civilian knowing, or at least believing, in common w:th all the wisest authors: and students of international affairs, that great dangers are in store for our race and pressing on us quickly-social changes, European changes, naval changes, and changes in the Pacific, which is about to become the new centre of the strategy of mankindmay I impress upon you the words of one of the freshest of all new politicians, the great Japanese : publicist, "authior of the " Risen Sun," Baron Suyematsu. He has written on the subject of Bushido, which the lecturer translates into chivalry. Here is a summary of Bushido, Bushis became Daimios by their personal valour and the honour they had attained or won. The successive stages of the military class always handed down the same sort of sentiments and notions as their predeccssors. They were men with healthy notions of manliness. : Wisdom and learning they revered. Truth and self-sacrifice they worshipped. "Bushido" then is no other than the ideal code of military honour and discipline. Bushi were exactly like Spenser's knights, "right, faithful, true, they were in deed and word," and like Chaucer's knight, "gladly wolde they lerne and gladly.teche." Like "St. George of Merrie Englande the signe of victoric " they were loved and honoured by the faire," and by his side a lovely ladye rode, upon a lowly steede as white as snow, herself much whiter." Here you have chivalry, horsemanship, the knight, the hero, not in confidential anonymous reports, not in "miching Mallcch" or sneaking mischief, not in paitry spectacles by hired mercenaries of the foot. Not in dishonoured though costly parodies of equity by partisan lawyers: The modern British officer should be Bushido incarnate, and he would be the very ideal soldier if allowed by the kaleidosoopic machinery of a Council, which as Langlois says, tergiversera toujours, 
or if not bound by the very cheap but all-embracing tape of extemporising boards! whose only. valour is the torpor of ignorant inefficiency. : The potentialities of your, race must necessarily, be entrusted to the officers of your Navy and of your Army. All our hopes ${ }_{i}$ and all the hopes of our children are bound: up in their careers. You cannot treat them too well, you cannot give them too much, you cannot edicate them too splendidly. Everything that is lofty in human, nature should be concentrated in, their brains and in their bodies-everything that is fine in art should be lavished on their perfect manhood...That ought to be our ideal. I beg of this audience, and of every other audience; and of you, my Lord, hoping that you and your friends may have time to soon realise these aspirations, to see to it that these officers of the Army are not presented to public : pity in another year or so in the disparaged and miserable condition that they are in now as to pay and other conditions of comfort and repute-inferior; in numbers, with a farcical education, but that they are treated at least as generously as attorney generals or solicitor generals, or any other agents of either chicanery or honour, that they are treated in a mariner worthy of the traditions of an Imperial Race. To neglect or disparage, to cheat or to humiliate our officers, or our privates, for that matter, and thus produce a shortage, and to degrade the Profession of Arms, is to stab the future of our. Empire in the heart.

Colonel W. T. Dooner (late Royal Inniskilling Fusiliers):-I sincerely wish that I had had the good fortune to have been called on to speak before Dr. Miller Maguire; as.:I fear that after: his eloquent speech I can hardly hope to keep your attention even for a few moments. I rise to call attention to one point in connection with the deficiency of candidates for Woolwich and Sandhurst that the lecturer has not touched upon in his paper, and which none of the speakers have referred to. It is a point that I think has had the greatest effect in diminishing the number of candidates for both Woolwich and Sandhurst-I allude to the change in the age for admission which was made some years ago. Up to a $\cdot$ few years since any boy at a public school could go up for Woolwich after his sixteenth birthday, and to Sandhurst after his seventeenth birthday. Then a great and; in my opinion, a very unwise change was made. I believe it was made: $s 0$ as to: encourage University candidates to join the Army; but whatever the reason was, I am as convinced as I possibly can be that it has had more to do with reducing the number of candidates for Woolwich and Sandhurst than almost all the points the other speakers have referred to, such as confidential reports, small pay, and everything else. It works in this way: A boy now cannot go up for Woolwich or Sandhurst until he is eighteen years of age. His parents, therefore, are compelled to keep him at a public school much longer than formerly at nuch expense $\rightarrow f_{1}$ iso to $f_{200}$ a year-because all parents, I think, endeavour to send their sons to public, schools, and the lecturer has pointed out how anxious the War Office : has ben to get public school boys to compete: for the Army. The result of this is that these boys are kept up to cighteen years of age," and then if they are a bit lucky about the month of their 'birth-this is a very important point-if they have, fortunately for them and their parents, been born shortly before the Ist of June or before the Ist of December, they can then go in for the halfyearly examination that usually takes place in these months. But if they have been born in June or December they cannot go in for another six months. It so happens, therefore, that many candidates cannot compete until they are eightcen and a quarter or nearly eighteen and a half 
years of age; and if sucoessful at their first trial they have then to study at Woolwich or Sandhurst for two years more, so that a boy, no matter how clever he may be, cannot get his commission in the Army under present rules until close on' his 'twenty-first birthday. $:$ If 'successful at his second or third trial he is, of course, proportionately dider. I venture to think that at' 21 or 22 years of age is a great deat too old to join the :Army.' In : connection with this point : I thought. I would look up ijust now in the Army List the ages at which all our Field. Marshals entered the' Service. Lord Wolseley joined when he was eighteen years and nine months old; H.R.H. the Duke of : Connaught joined when he was eighteen years and one month old; Fiek-Marshal Lord Roberts was a little older, nineteen years and two months; Sir Evelyn Wood was seventeen years and seven months; Sir George White eighteen years and four months; Lord Grenfell, eighteen years and three months; Sir Chärles Brownlow was only sixteen years of age; and Lord:Kitchener seems to have been the oldest of them all, for he joined when he was over twenty. If these inwise age rules that have been recently brought into force to prévent boys' and youths going into'the'Army had existed when all those Field-Marshals joined, I wonder how many of their parents 'would have -kept them on waiting at public!'schools 'or ' whether they would have risked 'possible failure and perhaps 'induced ' their 'sons to choose some other profession. I say we are losing many valuable boys from the public schools as candidates for the Army by this rule with regard to eighteen years of age, and the Wari Office have at length apparently reognised it, as I saw an announcement in the papers yesterday that from June next the age is to be reduced to seventeen and a half ;'so that the authorities have only gone halfway. I should like to suggest that they should reduce it to seventeen, or even to sixteen and a half years. There is no valid reason which $I$ : know of why, if a clever boy is able to pass the test, he should not go in at sixteen and a half years and enter the Army at or after eighteen years of age in the same way as most of the Field-Marshals whose cases: $\mathbf{I}$ : have given. It costs ' realty about $f_{400} \therefore$ to keep a boy at a public school t' for two extra years till he is eighteen years old, and supposing he fails the first time; where is he then?::' $\mathrm{He}$ can go up for three times; he may fail twice, and then comes the third and worst trial of all. Most of us are aware that the public schools do not care about keeping boys after they' are 'nineteen; or a little older, so that the boy has:to leave and throw himself at the feet of some'kind teacher like Dr. Miller.Maguire, or somebody else, to try and help him for his last chance, and should he fail his plight is a most unhappy one, as he has not received a suitable education for any other profession. and you, my Lord, are also aware, that in connection with this age question there are some difficulties, but none of them unsurmountable. The Indian Government, for instance, object to take lieutenants because they get a littic better pay-about 50 rupees a month-where the establishment should be. second lieutenants, and thus the War. Office are in a little difficulty naturally, because they do not like to send young officers out to India'before they are twenty years of age, following the same rule that applies: to the men. But I think that could be very easily got over. If difficulties of that kind arise with regard to India, I think it would be very 'simple and easy to keep the second lieutenants with the Home battalion until they reach the necessary age, just like we keep the men. We have the same difficulty with the drafts, and I think we could keep the young officers at home just as we do 
the men. I suggest that the age should be reduced to at least seventeen, and that the IVar Ofice by this time next year should allow all boys, if so desirous, to compete for Woolwich and Sandhurst immediately after their seventeenth birthday. I know two boys àt the present moment, one at one public school, and one at another. They are both seventeen years of age, and they have had the misfortune and annoyance during the last examination and the examination before of seeing boys, their seniors in age, in the forms below them going into Woolwich or Sandhurst while they themselves have had to mark time, and are marking time at this moment because they. are not eighteen years of age. Is not this absurd, in view of the ages at which the Ficld-Marshals of the British Army entered it, which $I$ have given you? If this rule had applied to them they would have been marking time at the public schools when most of them had already joined the Army. I now pass to another point, examinations, with which $I$ have had much to do, and I certainly think that the examinations for promotion might be a little less severe for those who only aspire to regimental work. I know we all say, how is it officers cannot pass these baby examinations? I remember the case of an oflicer that I did $\mathrm{my}$ best to get through. He was a captain. The qualifying marks were 1,20o. That officer worked as hard as any man could work, but unfortunately he only made 1,183 ; he failed by 17 . I remember that $I$ was out in Phœnix Park one afternoon when I saw this very officer dressed up in marching order, with three or four men of his company, training and exercising to try and win the marching order race in the garrison sports. In my opinion that was not an officer - he was a good regimental officer-to turn out of the Army simply because he was a little mixed about magnetic variation, or could not solve some conundrum about Contours or Military Law. But out he had to go on $f 200$ a year. One of the speakers has referred to the question of confidential reports. For myself I do not see how they are to be done away with. I think a commanding officer has no more important duty, and one which he does more conscientiously, than the making of those confidential reports.

\section{Major Hawksinw :-Not always.}

Colonel Dooser:-I think he always does them conscientiously. If the regulations are carricd out-and every commanding officer, I presume, does carry them out-if he is driven to say a word against an officer, he has to call him in and say: "My dear fellow, I have tried to sec an improvement and I cannot, and I have to so inform you." I had to say to one officer: "I am asked whether you are a good horseman, and $I$ have never seen you on a horse in my life. How do you suppose I am going to answer that?" He decided to go to the Riding School, and after the usual course he turned out a very fair horseman. My ten minutes have expired and, therefore, there is no time to refer to the question of pay, but I do hope, Sir, that if we ever see you at the War Office again you will try and raise the pay of the subalterns, at any rate in India. It does seem ridiculous that the subalterns of the British Army have to be soldiering on lesser rates of pay beside the subalterns of the Indian Army, where, as General Hutchinson has told us, they have not the slightest difficulty in getting candidates. The British subaltern does not get the same rate of pay, and naturally the grievance is very great. I had intended to say something about the dates fixed for the qualifying examinations, and other things.

VOL. I.IV. 
but I will only in conclusion add that I consider the question of the age at entry into Woolwich and Sandhurst is the most important point of all, and that it certainly should be reduced to seventeen or less.

Colonel H. H. A. StEwart (late Donegal Artillery):-I quite agree with what Colonel Dooner has just said about the age at which candidates should enter Woolwich and Sandhurst. There is not the slightest doubt that seventeen ought to be the age, if not sixteen. A great deal has been said about the pay, especially of the junior ranks, of the subalterns of the Army. We apparently have lost our initiative in everything, even in raising the pay of the officers of the Army. This initiative has been taken quite recently by our gallant allies the Japanese, who are at once going to raise the pay of the officers throughout their army by 30 per cent. The reason, in my humble opinion-and I have served for many years in the Regular Army and Militia-of the shortage is, as I think General Hutchinson said, the insufficient pay. A very trite saying was quoted by the lecturer of the German General Von der Goltz, namely, that the officer of the army should have such emoluments as to render him free from care. I can honestly say that as a subaltern for ten or twelve years in my regiment the greatest care that I had-and many others in the regiment, too-was how we were going to pay our mess bills every month. The lecturer mentioned that he considered-and I think very rightly-that the allowance to an officer in the infantry ought to be about Eloo a year. I daresay the Chairman will remember the fact that, I think it was, Lord Esher's commission,1 which sat about seven years ago, stated in their report than $£ 60$ a year ought to be sufficient for a subaltern in an infantry regiment, and for a subaltern in a cavalry regiment $f_{200}$ a year-in an ordinary cavalry regiment-not the fancy ones. But I am of the opinion that $£ 60$ a year for the infantry branch of the Service, in which I served, is not sufficient, and especially so in India. My son, who is in an infantry regiment, returned home on leave a few months ago from India, and he says he found it more difficult to live there on his allowance than he did when he was at Aldershot. I think I may say it is the fceling of the meeting that an impartial enquiry into the cause of the shortage of officers is imperatively required, and the sooner it is begun the better.

The Chalrman (Viscount Midleton):-I have the honour of saying a few words in closing one of the most interesting discussions at which I have bcen privileged to attend. I have not before had the pleasure of presiding at one of these meetings, but I can say honestly that during the somewhat long period that I was engaged in different capacities at the War Office I received the greatest possible advantage by reading from time to time the discussions which occurred here which bore upon my work there. And I must say that I do not think any question which you have taken up here requires so much treatment as the one which our lecturer this afternoon has so well discussed. I ought perhaps to say at

1 My memory was here at fault somewhat; it was a Committee presided over by Lord Stanley (Financial Secretary to the War Office), to which 1 meant to refer; its Report, signed by all the members and dated 21st July, Ig02, sets forth in paragraph $78:$..." Such disbursements could be covered by $£ 60$ a year as a minimum (and certainly within $\in$ froo) in the case of an infantry subaltern officer." . . . . For a subaltern of cavalry the Committee recommended an allowance of about "double the "above amounts."-H. H. A. S. 
the outset that in all these things any man who has borne a position at the War Office, whether it be military or civil, must take some small share of responsibility, although of course the larger share will always rest with the Secretary of State. I thought I came very well out of Dr. Miller Maguire's remarks this afternoon. His view of the Secretary of State' is similar to that of the great Lord Wellesley, who, when he was once asked what he thought about Dr. Johnson's verses, after.impressing on his questioner the necessity of secrecy as to his opinion, expressed the view that they were all bad, but some were possibly worse than others. I believe that Dr. Mliller Maguire holds very much that view of Secretaries of State. I may further say that those wise men-if they were wise-who, after I left the War Office, exchanged the authority of the Secretary of State in many respects for that of the Army Council, and who thereby set up a buffer between the Secretary of State and the public, were justified in doing so, because the specch which we heard from Dr. Miller Maguire certainly left very little superfluous skin upon the Army Council. I am quite sure that in all these matters we ought to look not merely at what the individual is able to do for this or that subject, but we ought if we can on such occasions as this to consider how much influence we can collectively bring to bear to forward any particular change or any particular development in Army policy. All these things are not made in a moment. Our present difficulty, if I may say so, is the natural outcome of the South African War. The South African War obliged us to commission a very large number of officers in a very short time. It brought to light certain defects in training, though certainly not anything in the character of our officers, which would justify, as Major Churchill admirably pointed out, the attacks which were indulged in at that period. But while further qualifications were asked for, I can say from personal experience that $I$ found it almost impossible to bring home to others-and I must say that those who advised me on the military side also did not feel at that time the necessity of realising-that if you were going to make the Army a profession for officers in which a man would be as hard worked as in the civil profession, that his chances must be in some degree equivalent to those of the civil professions, and that you must'adopt a higher system of payment; that you must make the attractions of the Service more what they are in the Indian Service, as General Hutchinson said. I have always felt that the attempt to screw up, if I may. use the expression, the requirements of officers, and at the same time not to provide them with additional attractions, might result, as it has resulted, in a shortage of the number of candidates. I do not say that nothing was done to try and meet them. In the cavalry, particularly, an effort was made by giving officers the opportunity of taking Government horses on very moderate terms. I have heard of many cases where fathers were able to send: their sons into the-cavalry through that who could not afford to do it before, when there was so heavy an outfit to provide; and some other changes were made, in addition to which it was held by the military authorities that the too frequent changes of stations might be to some extent arrested, and alterations were made with regard to the mess, furniture, and so forth. But the main question remains unsatisfied. If I may be allowed for a few moments to say what strikes me most of what has passed this afternoon, it is I think, that the cost of creating a general staff for the Army, despite the desire of everybody that we should go out largely in the direction of the general staff, has had a very serious effect in some respects on the prospects of. the regimental officer. Everybody knows that the regimental officer is 
the backbone of the $\Lambda$ rmy. I lope you will not think that I am trying to justify one régime at the IVar Office or to attack another; there is not a word of that in what I desire to say. I am thinking of the War Office as a whole. I am thinking of the military and Army policy as it ought to be, something which is to be consecutively developed towards a higher end. There is no doubt, however, that in the course of the last three or four jears the estimates have been increased by over half a million of money. Anybody who has had anything to do with the military forces of this country must linow that when you are increasing largely in one direction you generally find there is a movement to economise in another. I personally have always greatly regretted any reduction in the number of regimental officers, because 1 am quite certain that if a war breaks out again that would probably be our weakest point. The disturbance is, of course, very great. When you reduce a regiment you have to absorb the officers. I remember an occasion when it was sinuply a question of absorbing one or two quartermasters out of two battalions which had existed for a very short time, the Liverpool Regiment. We had the greatest difficulty in getting any regiment in the Army to stop their promotion in order to put them in. But there is another and a much more serious difficulty. Major Churchill spoke of the relations between the staff and the Army. In one passage he particularly referred to this difficulty where he said, "Our system aims at securing a staff officer and employing him under widely varying conditions and circumstances rather than restricting his employment to that particular sphere in which he displays marked ability." May I say one word on that, because I do think that if the idea is what I suppose it to be, that rather runs counter to the conceived idea of how you can best develop the usefulness of your staff. I think I am right in saying-there are critics who know nore about foreign armies than I do at present-that in the German army no man who serves on the staff is allowed to remain there long without in his earlier years being sent back to a regiment. I myself had a long convergation with an officer not long ago who belongs to the German general staff, who told me that he had been sent back first to serve in an infantry regiment, afterwards for a year and a half or two years in a cavalry regiment, while he was afterwards attached to an artillery battery in order that he might know, see, and understand every department of the Service before he was finally fixed in the general staff. I cannot help thinking that there is a great advantage in that view. 1 do not think that the regimental officer should be entirely cut off from staff work, nor that the staff officer should be entirely cut off from regimental work. I think the division as betwcen staff and regiment has sometimes led to a very great hiatus between the IVar Office and the Army itself. For that reason, although in later years no doubt it may be well after a period to fix an officer in the particular line which he is going to adopt, I would suggest to the lecturer that that should not apply to the earlier years of his service. Now, ladies and gentlemen, what do we come to as to the criticism of our present position? There is first the question of pay, and that I imagine, if the present shortage of candidates continues, must ultimately be taken up as a business question. You cannot ask a man to give up his time, and work as he is now supposed to work and must work if he himself and those under him are to be efficient, without, at the same timc, making it, so to speak, worth his while, or at any rate worth his father's while, to send him into a profession which is paid so badly as at present the Army is. May I remind you that, even in the last ten years, the classes from which 
we must take our Army officers have become themselves much more luxurious, and undoubtedly spend more than they did. You cannot expect to put, as it were, a "ring fence" round the officers of your Army, and I often wonder how in the sister Service they contrive to do it. Further, I hope we are about to reach a period when we may come to bedrock in the changes which have been going on in Army matters for the last twenty years. There has hardly been a moment during that period when the question of Army reform has not been put before the public. I confess that I personally should be only too glad if we could adopt some scheme on Army matters to shut up both Parliament and the IVar Office for a short time, ard thus enable the Army to fight out its own salvation; at all events to give everybody a sense that their career, and the circumstances under which they enter it, will remain a fixed quantity, and give them a chance of going ahead. I will not enter into the questions with regard to the examinations, becnuse they have been discussed so very admirably this afternoon, except I night perhaps mention that I was a little struck with the repartee which the Civil Service Commissioners made to the IVar Office. I looked inside the report to see whether I had been the cause of it, but as I found the letter was dated a year after I ceased to be responsible, I felt that I had in military parlance got out of range. In the same way with regard to these examinations, I do not think the present system has been very satisfactory, and one of the most valuable results of this discussion will be that it will bring before those in authority the place where the shoe pinches, and will probably enable them to adopt some system which will in future give us an actual entrance examination to Sandhurst and Woolwich, which has been suspended for the last year or two. And now I feel I must not keep you any longer. I believe that the officers of the Army to-day are in a valley between two mountains-the mountain of the past when less efficiency was asked for, when there was less organised attempt to get up to the highest level on the part of the officers whom we engaged, but when on the other hand we had a more attractive Service and a larger number of people who could not find an outlet for their energies, and who were glad to go into the Army. But to-day we have got far nearer to Continental armies in our idea of our requircments, and the sacrifices we must call upon our officers to make. We have not, on the other hand, come up, as I think, to the commercial standard which we must some day reach if we are to induce men of the highest patriotism to place themselves in the position which our officers have to fulfil. The suggestion was made that we should take it from those who are above in order to meet the necessities of those who are below. This is the only criticism I wish to make in the course of my remarks. I do wish the officers of the Army, especially those who serve at headquarters,, would try and keep civilians straight by themselves carrying on a consecutive policy. I have seen with the deepest regret that the higher commands, for which, after the war, with very great difficulty we obtained from the Treasury a tetter standard of remuneration than they had before, especially the commands at Aldershot, in Ireland, and on Salisbury Plain. have been reduced. The Generals who felt it quite impossible to take up a command, and do all that was necessary, and who could not possibly make both ends meet, did receive after the war a sum which made it possible for them to live. Now when I take up the estimates in the Army List I find that in every case those figures have been subsequently clipped. Only the other day I came acnoss an officer who told me that he found it quite impossible to make both ends meet where he was, and 
I really had great difficulty in refraining from saying, "But, sir, you jourself were at the War Ofice when the arrangements wcre recently made, whereby the amounts were reduced to their present extremely small level, and you yourself were the most responsible for it, because if I mistake not, you were the person who suggested it." I have let my soul go on that subject this afternoon. I say that if you can, at such discussions as this, concentrate military opinion on certain points, believe me that although it may not bear fruit immediately it will not be neglected, because there is a genuine desire on the part of those who now administer the Army not to jog along in the old ruts, but to obtain efficiency-and to obtain efficiency by asking the nation, as far as they can, for the supplies which are necessary. I apologise to you for having taken up your time for so long, but I conclude by moving a most hearty vote of thanks to Major Churchill for his excellent address. 